\title{
Topographic Variation in Structure of Mixed-Conifer Forests Under an Active-Fire Regime
}

\author{
Jamie Lydersen ${ }^{1 *}$ and Malcolm North ${ }^{2}$ \\ ${ }^{1}$ Graduate Group in Ecology, University of California, Davis, One Shields Ave., Davis, California 95616, USA; ${ }^{2}$ U.S. Forest Service, \\ Pacific Southwest Research Station, 1731 Research Park Dr., Davis, California 95618, USA
}

\begin{abstract}
Management efforts to promote forest resiliency as climate changes have often used historical forest structure and composition to provide general guidance for fuels reduction and forest restoration treatments. However, it has been difficult to identify what stand conditions might be fire and drought resilient because historical data and reconstruction studies are generally limited to accurate estimates only of large, live tree density and composition. Other stand features such as smaller tree densities, dead wood, understory structure, regeneration, and fuel loads have been difficult to quantify, estimate how they may vary across a landscape, or assess how they would be affected by fire under current climate conditions. We sampled old-growth, mixed-conifer forests with at least two low-intensity fires within the last 65 years in 150 plots at 48 sample sites ranging
\end{abstract}

\section{INTRODUCTION}

A dilemma for scientists and managers is how to improve the ability of ecosystems to cope with environmental stress under changing climate conditions, often in the absence of historical distur-

Received 19 December 2011; Revised 26 April 2012; accepted 3 June 2012; published online 26 July 2012

Author Contributions: JL designed study, performed research, analyzed data and wrote the paper. MN conceived of and designed study, analyzed data and wrote the paper.

*Corresponding author; e-mail: jmshields@ucdavis.edu over $400 \mathrm{~km}$ of the Sierra Nevada. Recent fire history had the strongest influence on understory conditions with small tree density decreasing and shrub cover increasing with the increased intensity and frequency of fire associated with upper-slope and ridge-top locations. In contrast, stand structures associated with large, overstory trees such as total basal area, canopy cover, and the abundance of large snags and logs increased in topographic locations associated with more mesic, productive sites regardless of fire history. In forests with restored fire regimes, topography, fire and their interaction influence productivity and burn intensity, creating the structural heterogeneity characteristic of frequent-fire forests.

Key words: fire frequency; mixed-conifer forest; Sierra Nevada; topography; tree mortality; wildfire.

bance patterns. This is particularly important for forests because they store more than double the amount of carbon present in the atmosphere (FAO 2005; Canadell and Raupach 2008), yet may be experiencing increasing mortality rates associated with the warming temperatures of recent decades (van Mantgem and Stephenson 2007; van Mantgem and others 2009). Furthermore, the incidence of large, stand-replacing fires is increasing in some Western forests (Miller and others 2009). Research in forests maintained by active, low-intensity disturbance regimes suggests they may be more capable of maintaining and recovering ecosystem 
functions in the face of drought, fire, and insects. The resilience of these forests may be attributable in part to their structural heterogeneity (Fulé 2008; Stephens and others 2008; Virah-Sawmy and others 2009).

Many forest managers in the western U.S. have struggled with how to create this heterogeneity while reducing the risk of high-severity fire and maintaining ecosystem services such as habitat provisioning for sensitive species (Hessburg and others 2007; North and others 2009; Underwood and others 2010). One common approach has been to use limited historical data or reconstruction methods to estimate forest conditions produced in the past by frequent-fire regimes (for example, North and others 2007; Scholl and Taylor 2010; Collins and others 2011). Although these studies can provide some insight into historical large, live tree structure and composition for particular sites, there are at least three aspects of frequent-fire forests that have been difficult to quantify: (1) understory, small tree density, coarse woody debris, and fuel conditions (Stephenson 1999; Laughlin and others 2004; Collins and others 2011); (2) how forest structure, composition and fuels may vary with topography across a landscape (Keane and others 2009); and (3) what forest conditions would be produced by recurrent low-severity fire under current climate conditions (Millar and Woolfenden 1999; Stephens and others 2003).

Fortunately both Yosemite and Sequoia/Kings Canyon National Parks recognized the importance of fire as an ecosystem process and began to allow wildland fire use (now termed "managed wildfire" $^{\prime \prime}$ on some of their lands starting in the late 1960s and early 1970s (van Wagtendonk 2007). To a lesser extent, the Forest Service adopted a similar policy of "managed wildfire" in a few remote areas. Wild- and prescribed-fire are allowed to burn under favorable weather conditions (that is, generally supporting low and moderate severity burn effects) and many of these areas now have repeatedly burned at frequencies and intensities approaching patterns described in fire history studies (Collins and others 2007). Forest conditions in these areas are not confounded by past timber harvesting and contain large trees, snags, and logs characteristic of older forests (Stephens and Fule 2005). These areas represent a rare opportunity to study forest conditions produced by restoring fire patterns under current climate conditions, which hereafter we refer to as an active-fire regime.

Objectives of this study were to quantify the stand structure, composition, and fuel loads of modern active-fire forests, and to determine how these forest attributes varied with recent fire history and topographic position (slope position and aspect). Data were collected from stands of oldgrowth fire-dependant forests in which a frequentfire regime has been restored for several decades. Our objectives were to determine: (1) the size class distribution of live stems; (2) how forest structure varies with topographic position; and (3) what site factors are associated with differences in understory structure. Understanding how forest heterogeneity is produced by restored disturbance regimes under current climate conditions may help inform managers in establishing broad guidelines for treatments aimed to increase resiliency and habitat variability in fire-dependant forests.

\section{MethodS}

\section{Identifying Candidate Stands}

Candidate study areas were identified from stands within the Sierra Nevada based on forest type, recent fire record, and old-growth status using Arc GIS version 9.3 (ESRI 2008). We focused on mixedconifer forests, with some lower elevation sites having a combination of ponderosa pine/mixedconifer conditions. Prior to the implementation of fire suppression policy in the early 1900s, these forest types had a frequent ( $<20$ years), lowseverity (generally surface burn) fire regime (Skinner and Chang 1996).

Candidate study areas were selected from stands in which frequent-fire regimes have been restored. Our definition of a restored, or active-fire regime required stands to have experienced at least two low-severity, surface fires in the last 65 years, one of which occurred within the last 30 years. Although our definition of an active-fire regime has a lower fire frequency in the last 65 years than would have occurred historically, recent studies have suggested that forest overstory and understory may approach historical structure after two burns (Taylor 2010; Webster and Halpern 2010) (or in some cases one moderate severity fire may be sufficient (Collins and others 2011)). Most study areas had patches of high-severity fire within the burn perimeter, which were avoided. Severity levels were determined by the National Park and Forest Service analyses using imagery and the change (delta) in the Normalized Burn Ratio (dNBR). A relativized dNBR compares changes in the amount of photosynthetically active vegetation that is present pre- and post-fire, accounting for initial variability in pre-burn vegetation conditions. It is a widely used method for accurately classifying 
burn severity at a moderately fine scale (Miller and Thode 2007). Although vegetation damage and mortality within low-severity burns areas were generally low, field observations suggest fire intensity, a measure of the energy released by a fire (sensu Keeley 2009), was often quite variable.

To avoid confounding the effects of recent fire and past logging activity on forest structure, we only selected sites that had never been thinned or salvage logged. We first assessed the old-growth status of candidate stands using the ranking developed for the Sierra Nevada Ecosystem Project (SNEP) (Franklin and Fites-Kaufmann 1996). This ranking classifies stands based on their physical features and overall contribution to old-growth functioning in the Sierra Nevada. The absence of thinning was then verified in the field; if signs of prior harvest were evident we did not sample in the area. Several areas that were classified as oldgrowth under the SNEP rankings and were initially identified as potential study areas were excluded based on the presence of older stumps throughout the site. Due to this stipulation, most of the data in this study comes from National Park Service land.

Using these criteria we identified 24 study areas ranging over $400 \mathrm{~km}$ of the Sierra Nevada (Table l; Figure 1). Several study areas had multiple combinations of overlapping burn perimeters created by different fires. Sample sites within each study area were defined as sites with a unique combination of fire events that meet our criteria listed above. Overall we identified a total of 48 sample sites with unique fire histories within the 24 study areas. Within sample sites, plot locations were stratified by topographic categories (described below) and separated by changes in slope, aspect and intervening landscape features to significantly reduce spatial autocorrelation in fire effects on forest structure (van Mantgem and Schwilk 2009; Webster and Halpern 2010). All sample sites experienced between two and four fires total. Fires consisted of both wildfire and prescribed-fire, which, under some conditions, can have comparable effects on forest structure when burning at low-severity (Nesmith and others 2011).

\section{Field Measurements}

Within each sample site with a unique fire record, plots were located based on a topographically stratified random sample. Plots were categorized based on aspect, slope position (lower-, middle-, upper-slope or ridge) and slope shape (concave, flat or convex). We used the same categories for slope position as Parker (1982), with the exception that valley bottom and lower slope were combined due to their similar influence on fire intensity. These topographic categories were chosen because we were interested in using a quantified, repeatable classification successfully used in other studies (Bekker and Taylor 2001; Taylor 2010) that could be readily applied in the field. We were stringent in sampling only locations that could be clearly assigned to a topographic category. Within each sample site we attempted to sample as many unique combinations of these topographic categories as possible, however, because sample sites varied in size and topographic complexity, it was not possible to include every topographic category in all sites. Overall we sampled 150 plots. Each topographic category was broadly represented across many sites, and there was a similar distribution within topographic categories of other subclasses (Table 2).

For each $20 \mathrm{~m} \times 50 \mathrm{~m}$ rectangular plot, elevation, slope position, aspect, steepness, configuration, and distance to perennial stream were measured. Surface fuels were measured along three $15 \mathrm{~m}$ transects following standard protocol (Brown 1974). Live trees and snags were sampled in nested rectangular plots. Trees and snags smaller than $50 \mathrm{~cm}$ diameter at breast height (dbh) were measured in a $20 \mathrm{~m} \times 25 \mathrm{~m}$ area (0.05 ha), and larger structures $(\geq 50 \mathrm{~cm})$ were measured throughout the entire $20 \mathrm{~m} \times 50 \mathrm{~m}$ (0.1 ha) plot. For each tree, species, dbh, height to the base of the live crown, and maximum scorch height were recorded. For each snag, species, dbh, height, decay class (Maser and Trappe 1984) and maximum scorch height were recorded. Shrubs were identified by species and their percent cover was measured along a $50 \mathrm{~m}$ transect. Size and species of regenerating trees that were no more than $5 \mathrm{~cm}$ dbh and at least $10 \mathrm{~cm}$ in height were recorded in ten systematically placed $1-\mathrm{m}^{2}$ quadrats. Canopy cover measurements were taken with a sighting tube (densitometer) at 100 regularly spaced intervals.

\section{Analysis}

Our analysis was focused on two spatial scales; mean stand structure of active-fire forests and structural differences between topographic locations. Within a sample site, all plots were a minimum of $60 \mathrm{~m}$ from each other (average distance between plots $=1260 \mathrm{~m}$ ), and were separated by changes in topographic features. We treated plots as discrete samples, as variable topographic, forest, and fuel conditions usually create a fine-scale intensity mosaic within a low-severity fire perim- 
Table 1. List of Study Areas, Their Fire Events, Elevation Range, Extent and Number of Plots Sampled at the Site

\begin{tabular}{|c|c|c|c|c|}
\hline Study area (\#) & $\begin{array}{l}\text { Elevation } \\
\text { range }(\mathrm{m})\end{array}$ & $\begin{array}{l}\text { Size of study } \\
\operatorname{area}^{2} \text { (ha) }\end{array}$ & $\begin{array}{l}\text { Recent fire } \\
\text { record }^{1}\end{array}$ & $\begin{array}{l}\text { \# of } \\
\text { Plots }\end{array}$ \\
\hline Barkley (1) & 860 & 200 & 1994,1999 & 1 \\
\hline Bucks (2) & 1495 & 700 & 1951,1999 & 1 \\
\hline Eleanor North (3) & $1705-1995$ & 600 & 1986,1999 & 9 \\
\hline Laurel (4) & $1810-1935$ & 350 & $1978,1991,2005$ & 9 \\
\hline Eleanor South (5) & $1487-1781$ & 1000 & 1978,1996 & 9 \\
\hline \multirow{4}{*}{ North (6) } & $1522-1622$ & 2000 & $1950,1987,1996$ & 4 \\
\hline & & & 1994,1996 & 3 \\
\hline & & & 1987, 1996 & 3 \\
\hline & & & 1993,1996 & 2 \\
\hline Cottonwood (7) & 1787 & 50 & 1996, 2009 & 1 \\
\hline \multirow[t]{3}{*}{ Aspen Valley (8) } & $1547-1804$ & 1200 & $1983,1990,1999$ & 1 \\
\hline & & & 1983,1998 & 10 \\
\hline & & & $1983,1990,1998$ & 1 \\
\hline Gin Flat (9) & 1995 & 100 & $1989,2000,2002$ & 1 \\
\hline Tamarack (10) & $1884-2108$ & 350 & $1979,1980,2009$ & 12 \\
\hline Cascade (11) & $1894-1964$ & 100 & 1986,2007 & 3 \\
\hline \multirow[t]{3}{*}{ A-Rock (12) } & $1422-1792$ & 1400 & 1979,1990 & 8 \\
\hline & & & $1979,1990,2009$ & 1 \\
\hline & & & 1990, 2009 & 2 \\
\hline Grouse (13) & $1637-2085$ & 1100 & 1990,2009 & 6 \\
\hline Illilouette (14) & $1903-1960$ & 200 & 1991,2004 & 4 \\
\hline Mono (15) & $2131-2196$ & 150 & 1980,2004 & 3 \\
\hline Wawona (16) & $1273-1284$ & 150 & 1985,2005 & 2 \\
\hline \multirow[t]{3}{*}{ Lewis (17) } & $1797-2083$ & 1700 & $1980,1996,2005$ & 2 \\
\hline & & & $1980,1998,2005$ & 7 \\
\hline & & & 1980,2005 & 2 \\
\hline \multirow[t]{2}{*}{ Zumwalt (18) } & $1521-1570$ & 200 & $1995,1997,2006$ & 1 \\
\hline & & & 1997,2008 & 1 \\
\hline \multirow[t]{5}{*}{ Sugarloaf (19) } & $2178-2444$ & 1000 & 1974,1985 & 5 \\
\hline & & & $1974,1985,2003$ & 2 \\
\hline & & & 1974,2003 & 2 \\
\hline & & & $1974,1985,1997$ & 2 \\
\hline & & & $1974,1977,1997$ & 2 \\
\hline \multirow[t]{5}{*}{ Grant (20) } & $1833-2030$ & 200 & $1981,1995,2005$ & 3 \\
\hline & & & 1993,2004 & 1 \\
\hline & & & $1980,1993,2004$ & 1 \\
\hline & & & 1992,2005 & 4 \\
\hline & & & 1995,2009 & 1 \\
\hline \multirow{3}{*}{ Buena Vista (21) } & 2034-2284 & 100 & 1974,2004 & 3 \\
\hline & & & 1969, 1979, 1981, 2006 & 1 \\
\hline & & & $1979,1981,2006$ & 2 \\
\hline \multirow[t]{2}{*}{ Giant (22) } & $1783-1951$ & 50 & 1947,1988 & 1 \\
\hline & & & 1969,1978 & 1 \\
\hline \multirow[t]{4}{*}{ Atwell (23) } & $2067-2487$ & 500 & 1995,2003 & 2 \\
\hline & & & 1952,2005 & 1 \\
\hline & & & $1946,2000,2003$ & 2 \\
\hline & & & 1999,2003 & 3 \\
\hline Lion (24) & $2312-2316$ & 100 & 1975,2002 & 2 \\
\hline
\end{tabular}

Study area \# in parentheses corresponds to numbers in Figure 1. Some study areas $(N=24)$ had multiple sample sites (total $N=48)$, as sites were defined by a unique fire record. All sample sites experienced between two and four fires.

${ }^{1}$ Fire History was queried for years 1944-2009.

${ }^{2}$ Size of study area is a rough estimate based on overlapping fire perimeters, and does not take into account areas that were unsuitable for sampling based on fire severity or vegetation type. 


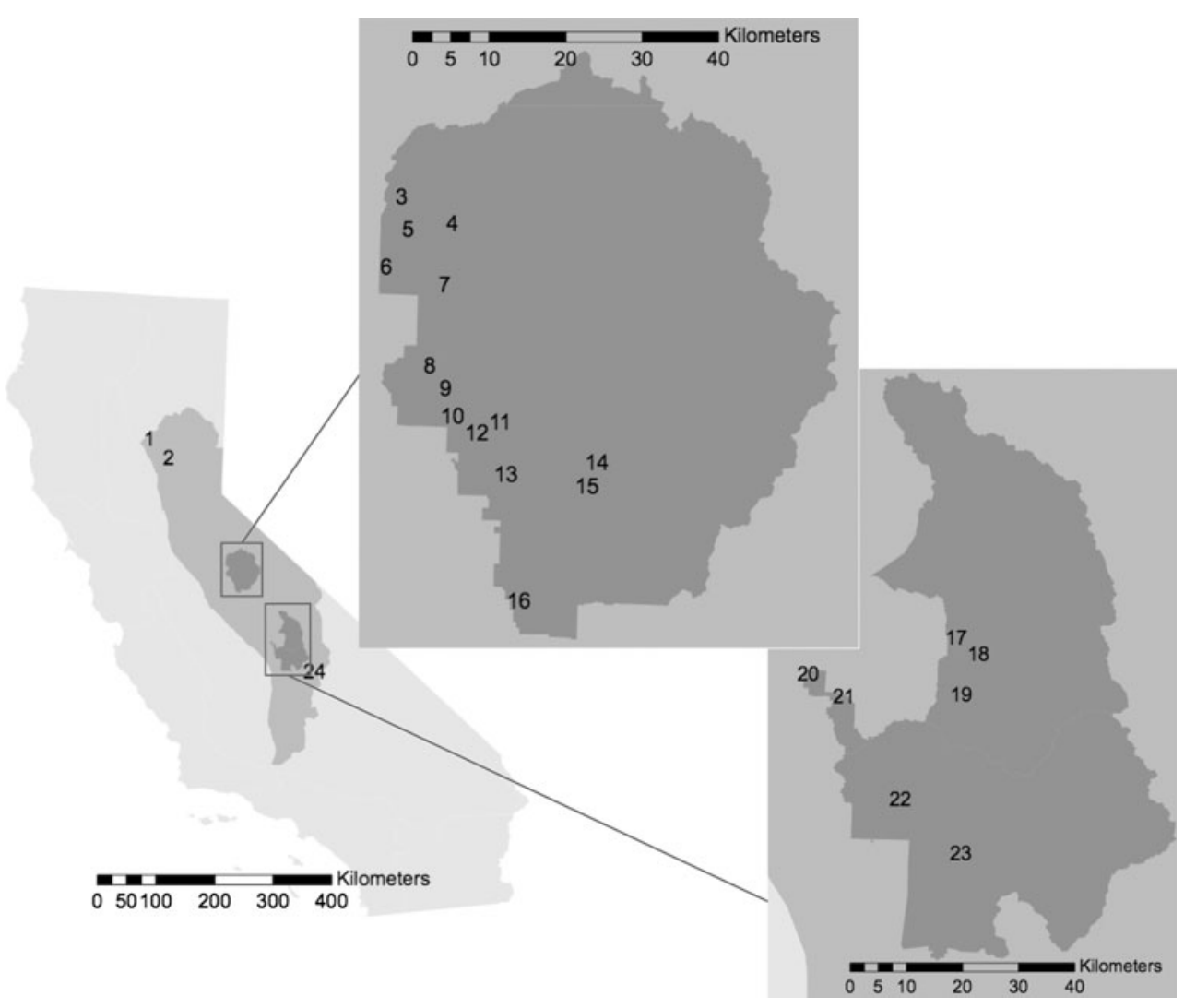

Figure 1. Map of study areas in California's Sierra Nevada. Study area numbers correspond to those in Table 1 .

Table 2. Distribution of Plots Among Topographic Categories

\begin{tabular}{llllll}
\hline $\begin{array}{l}\text { Topographic } \\
\text { category }\end{array}$ & L & M & U & R & $\begin{array}{l}\text { Total \# of } \\
\text { plots (sites) }\end{array}$ \\
\hline NE & $8(8)$ & $28(23)$ & $13(12)$ & $7(7)$ & $56(32)$ \\
SW & $12(9)$ & $44(27)$ & $24(17)$ & $14(13)$ & $94(40)$ \\
Total \# of & $20(12)$ & $72(36)$ & $37(26)$ & $21(20)$ & $150(48)$ \\
$\quad$ plots (sites) & & & &
\end{tabular}

Values represent the number of plots in each category, with the number of sample sites represented in parentheses. $L$ is lower slope, $M$ is middle slope, $U$ is upper-slope, and $R$ is ridge. Northeast aspect (NE) is $291^{\circ}-110^{\circ}$, Southwest (SW) is $111^{\circ}-290^{\circ}$.

eter. Although one study found little spatial autocorrelation in post-burn forest structure within a fire perimeter (van Mantgem and Schwilk 2009), we caution that issues of independence and pseudoreplication within a fire perimeter are still unresolved. If fire effects on forest structure are autocorrelated throughout a fire's burn area, our sample size would decrease to 48 and there would be fewer statistically significant differences between topographic categories.

A Topographic Relative Moisture Index (TRMI), a measure of relative soil moisture availability ranging from 0 (xeric) to 60 (saturated) (Parker 1982), was calculated for each plot location using slope position, slope configuration, aspect, and steepness. Slope aspect was cosine converted so that values ranged on a scale from 0 (xeric) to 2 (mesic), assigning $20^{\circ}$ as the most mesic direction to coincide with rules used in the calculation of TRMI. Maximum char height was averaged for the plot, and lacking direct observation or instrument data, we used this as an imperfect estimate of fire intensity (Andrews and Rothermel 1982). Because study areas had experienced multiple fires, we were unable to identify which fire caused the maximum char height. Therefore, our measure of fire intensity is not attributable to any one particular fire, but indirectly indicates the maximum intensity that occurred at a site over its recent history of fire events. 
To assess the size class distribution, live trees were divided into groups consisting of trees with dbh 5-19.9 cm, 20-39.9 cm, 40-59.9 cm, 60$79.9 \mathrm{~cm}, 80-99.9 \mathrm{~cm}, 100-119.9 \mathrm{~cm}$ and at least $120 \mathrm{~cm}$. Trees were further classified by fire-tolerance, with fire-intolerant species including Abies concolor, Abies magnifica, Calocedrus decurrens, and Pseudotsuga menziesii, and fire-tolerant species including Pinus ponderosa, Pinus jeffreyi, Pinus lambertiana, Quercus kellogii, and Quercus chrysolepis. Variables describing forest structure and fuel loads were compared between topographic stratifications using a mixed model ANOVA in SAS 9.2 for Windows (SAS Institute 2008). Topographic categories were considered fixed effects and sample site a random effect. Variables were checked for normality of residuals using normal probability plots and the Shapiro-Wilk test (Shapiro and Wilk 1965). All variables except canopy cover (CC), basal area (BA), percentage of shade-intolerant species (Shdint), and quadratic mean diameter (QMD) were determined to have residual distributions with significant departures from normality. Homogeneity of variances was assessed using plots of residual versus predicted values and a Levene test (Levene 1960). The variances of most variables were determined to be homogeneous; exceptions were basal area of fire-tolerant trees less than $40 \mathrm{~cm}$ dbh (Dens $40-80 \mathrm{~cm}$ ), percent shade-intolerant stems (Shd-int) and density of 100-h fuels (100-h). Logarithmic, power, and arcsine transformations were applied to improve normality of residuals and heterogeneity of variances, so that all variables did not deviate significantly from these criteria. Comparisons between means were made using Tukey's HSD (Honest Significant Difference) test (Zar 2010) and an alpha level of 0.05 .

Non-metric multidimensional scaling (NMS) was used to investigate site factors associated with all forest structures, understory and overstory only. Variables with highly skewed distributions were power- or log-transformed accounting for the lowest non-zero value (McCune and Grace 2002). NMS analysis was completed with PC-ORD 5.0 (McCune and Mefford 2006) using the "slow and thorough" setting and a Sorensen distance measurement. The primary matrix consisted of stand structure and fuel load measurements and the secondary matrix contained site characteristics (slope position, pitch, aspect, configuration, distance to water, time since last burn, number of fires in the last 65 years, interval length between the last two fires, and TRMI). For all three analyses we started with 6 axes, 50 real data runs, a maximum of 500 iterations, and an instability criterion of 0.00001 .
Following results from the NMS analysis, we divided our forest structure data into overstory and understory datasets for analysis using classification and regression trees (CART) in S-Plus 8.0 (Insightful Corporation 2007) to assess whether overstory basal area (trees with $\mathrm{dbh} \geq 80 \mathrm{~cm}$ ), understory density (trees with dbh $<40 \mathrm{~cm}$ ), and shrub cover differed by recent fire record and topographic conditions. Independent variables included topographic measures (TRMI, aspect, slope position, slope steepness, slope configuration, latitude, elevation, and distance to water) and fire metrics (time since last burn, total number of fires in the last 65 years, time in between the most recent two fires, and average char height) for the understory analysis and topographic metrics only for the overstory analysis. To aid in interpretation, regression trees were adjusted using a range of minimum deviations $(0.10-0.30)$, observations before split (5-20), and node size (10-40) depending on sample depth of the different variables.

\section{Results}

\section{Mean Stand Structure}

Measurements of average stand structure were highly variable across all sample sites (Table 3). Stand structure of all plots averaged $44 \%$ canopy cover, $54 \mathrm{~m}^{2} / \mathrm{h}$ a of live tree basal area, $123 \mathrm{~m}^{3} /$ ha of snags, $17 \%$ shrub cover, $0.6 \mathrm{stems} / \mathrm{m}^{2}$ of seedling and sapling regeneration $(<5 \mathrm{~cm}$ dbh but $\geq 10 \mathrm{~cm}$ in height), and $40 \mathrm{Mg} / \mathrm{ha}$ of total fuels. Standard deviations were particularly high for snag volume, log volume, shrub cover, regeneration, and surface fuel measurements. Quadratic mean diameter and canopy cover were the least variable, although their values still ranged considerably.

Although the number of stems generally decreased with diameter class, the greatest number of trees occurred in the second smallest size class (20$39.9 \mathrm{~cm} \mathrm{dbh}$ ). The three smallest size classes (stems $5-59.9 \mathrm{~cm} \mathrm{dbh}$ ) were dominated by fire-intolerant species, whereas in the larger size classes (stems $\geq 60 \mathrm{~cm} \mathrm{dbh}$ ) the proportion of fire-tolerant species increased with increasing size class (Figure 2).

\section{Topography and Stand Structure}

Stand structure was highly variable within topographic categories such that many variables were not significantly different between categories. Differences between slope positions tended to be greater than differences between aspects (Table 3). Slope steepness did not have a significant effect on forest structure. Canopy cover and basal area were 
Table 3. Mean Values of Structure Variables Across All Sample Sites, and by Slope Position and Aspect

\begin{tabular}{|c|c|c|c|c|c|c|c|}
\hline \multirow{2}{*}{$\begin{array}{l}\text { Forest structure } \\
\text { Variable }\end{array}$} & \multirow{2}{*}{$\begin{array}{l}\text { Mean } \\
\text { (St. Dev.) }\end{array}$} & \multicolumn{4}{|c|}{ Slope position } & \multicolumn{2}{|c|}{ Aspect } \\
\hline & & $\mathrm{L}$ & M & $\mathrm{U}$ & $\mathbf{R}$ & $\mathrm{NE}$ & SW \\
\hline CC (\%) & 43.7 (17.9) & $46.2^{\mathrm{A}}$ & $49.1^{\mathrm{A}}$ & $46.2^{\mathrm{A}}$ & $18.5^{\mathrm{B}}$ & $45.2^{\mathrm{A}}$ & $42.8^{\mathrm{A}}$ \\
\hline $\mathrm{BA}\left(\mathrm{m}^{2} / \mathrm{ha}\right)$ & $54.0(29.0)$ & $64.2^{\mathrm{A}}$ & $60.6^{\mathrm{A}}$ & $54.7^{\mathrm{A}}$ & $20.7^{\mathrm{B}}$ & $58.1^{\mathrm{A}}$ & $51.7^{\mathrm{B}}$ \\
\hline Dens $\left(\mathrm{ha}^{-1}\right)$ & $219.9(146.3)$ & $330.0^{\mathrm{A}}$ & $244.4^{\mathrm{AB}}$ & $176.8^{\mathrm{B}}$ & $111.4^{\mathrm{C}}$ & $243.0^{\mathrm{A}}$ & $205.5^{\mathrm{B}}$ \\
\hline Shd-int ( $\%$ of live stems) & $49.6(35.4)$ & $33.4^{\mathrm{A}}$ & $41.6^{\mathrm{A}}$ & $59.0^{\mathrm{B}}$ & $75.9^{\mathrm{B}}$ & $40.7^{\mathrm{A}}$ & $54.9^{\mathrm{B}}$ \\
\hline $\mathrm{QMD}(\mathrm{cm})$ & $66.1(16.7)$ & $63.4^{\mathrm{A}}$ & $66.4^{\mathrm{AB}}$ & $72.2^{\mathrm{B}}$ & $56.7^{\mathrm{AB}}$ & $67.4^{\mathrm{A}}$ & $65.3^{\mathrm{A}}$ \\
\hline Snag $\left(\mathrm{m}^{3} / \mathrm{ha}\right)$ & $122.9(246.5)$ & $260.8^{\mathrm{A}}$ & $108.3^{\mathrm{A}}$ & $91.3^{\mathrm{A}}$ & $97.5^{\mathrm{A}}$ & $171.2^{\mathrm{A}}$ & $94.2^{\mathrm{A}}$ \\
\hline $\log \left(\mathrm{m}^{3} / \mathrm{ha}\right)$ & $42.9(68.9)$ & $30.6^{\mathrm{A}}$ & $59.4^{\mathrm{A}}$ & $33.6^{\mathrm{A}}$ & $14.2^{\mathrm{A}}$ & $54.4^{\mathrm{A}}$ & $36.0^{\mathrm{A}}$ \\
\hline Shrub $(\%)$ & $16.9(23.0)$ & $12.1^{\mathrm{A}}$ & $15.1^{\mathrm{A}}$ & $19.5^{\mathrm{B}}$ & $23.1^{\mathrm{B}}$ & $17.8^{\mathrm{A}}$ & $16.3^{\mathrm{A}}$ \\
\hline Reg. Dens $\left(\mathrm{m}^{-2}\right)$ & $0.6(1.5)$ & $0.61^{\mathrm{A}}$ & $0.86^{\mathrm{A}}$ & $0.52^{\mathrm{AB}}$ & $0.12^{\mathrm{B}}$ & $1.01^{\mathrm{A}}$ & $0.42^{\mathrm{A}}$ \\
\hline Duff $(\mathrm{cm})$ & $2.1(1.8)$ & $2.0^{\mathrm{AB}}$ & $2.2^{\mathrm{A}}$ & $2.4^{\mathrm{A}}$ & $1.1^{\mathrm{B}}$ & $2.3^{\mathrm{A}}$ & $1.9^{\mathrm{A}}$ \\
\hline Fuel Ht (cm) & $6.2(7.1)$ & $7.5^{\mathrm{A}}$ & $5.7^{\mathrm{A}}$ & $7.6^{\mathrm{A}}$ & $3.8^{\mathrm{B}}$ & $6.2^{\mathrm{A}}$ & $6.2^{\mathrm{A}}$ \\
\hline l-h (Mg/ha) & $0.7(0.7)$ & $0.75^{\mathrm{A}}$ & $0.72^{\mathrm{A}}$ & $0.74^{\mathrm{A}}$ & $0.42^{\mathrm{B}}$ & $0.82^{\mathrm{A}}$ & $0.62^{\mathrm{A}}$ \\
\hline 10-h (Mg/ha) & $3.7(3.3)$ & $3.5^{\mathrm{A}}$ & $4.0^{\mathrm{A}}$ & $4.0^{\mathrm{A}}$ & $2.4^{\mathrm{A}}$ & $3.8^{\mathrm{A}}$ & $3.7^{\mathrm{A}}$ \\
\hline 100-h (Mg/ha) & $3.5(3.5)$ & $4.4^{\mathrm{A}}$ & $3.8^{\mathrm{A}}$ & $3.3^{\mathrm{A}}$ & $1.9^{\mathrm{A}}$ & $4.1^{\mathrm{A}}$ & $3.1^{\mathrm{A}}$ \\
\hline 1000-h (Mg/ha) & $32.3(41.4)$ & $36.8^{\mathrm{A}}$ & $37.2^{\mathrm{A}}$ & $31.9^{\mathrm{AB}}$ & $12.2^{\mathrm{B}}$ & $37.9^{\mathrm{A}}$ & $29.0^{\mathrm{A}}$ \\
\hline Ave Char Height (m) & $3.24(2.06)$ & $2.7^{\mathrm{A}}$ & $3.1^{\mathrm{B}}$ & $4.0^{\mathrm{B}}$ & $2.7^{\mathrm{AB}}$ & $3.0^{\mathrm{A}}$ & $3.4^{\mathrm{A}}$ \\
\hline
\end{tabular}

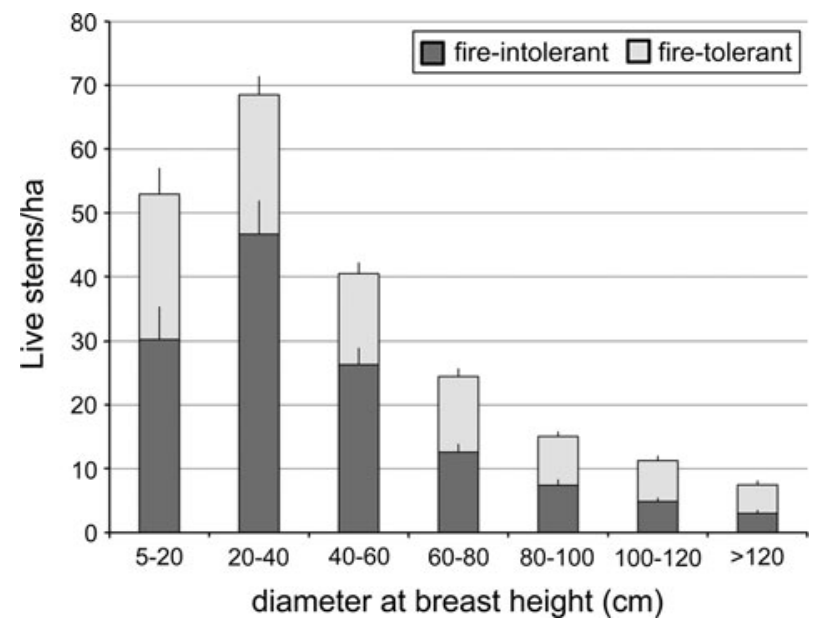

Figure 2. Average frequency of live stems by fire-tolerance in seven different diameter classes. Error bars show the upper half of the standard error for each class of firetolerance within a given size class. Averages and standard errors were calculated from data for all 150 plots. Fireintolerant species include Abies concolor, Abies magnifica, Calocedrus decurrens, and Pseudotsuga menziesii. Firetolerant species include Pinus ponderosa, Pinus jeffreyi, Pinus lambertiana, Quercus kellogii, and Quercus chrysolepis.

similar among lower, middle, and upper-slopes, but were significantly lower on ridge-tops. Live stem density tended to decrease, and the proportion of fire-tolerant species tended to increase in an upslope direction. This trend in live tree density was due to decreasing numbers of fire-intolerant trees, accompanied by more modest increases in the number of fire-tolerant trees, going from lower, to middle, to upper-slope positions. There was a decrease in the number of all trees, particularly fire-intolerants, going from upper-slope to ridge (Figure 3). Quadratic mean diameter was largest on upper-slopes, which had a relatively low stem density dominated by large trees. Snag volume was greatest on lower slopes, and similar among other slope positions, although it was highly variable and differences were not significant. Log volume was greatest on middle slopes, and lowest on ridge tops, although there were no significant differences between slope positions. Shrub cover tended to increase with slope position, with upper-slopes and ridges having significantly more shrub cover than lower and middle slopes. All size classes of downed woody fuels were sparser on ridge-tops than other slope positions (Table 3).

Differences between northeast and southwest facing slopes were generally small; although southwest aspects had significantly lower basal area, live tree density, and a greater proportion of fire-tolerant species. These trends in live tree abundance can be mainly attributed to the differing densities of small $(5-40 \mathrm{~cm}$ dbh) and large $(\geq 80 \mathrm{~cm}$ $\mathrm{dbh}$ ) fire-intolerant species (Figure 3 ). 
A Fire-intolerant Species

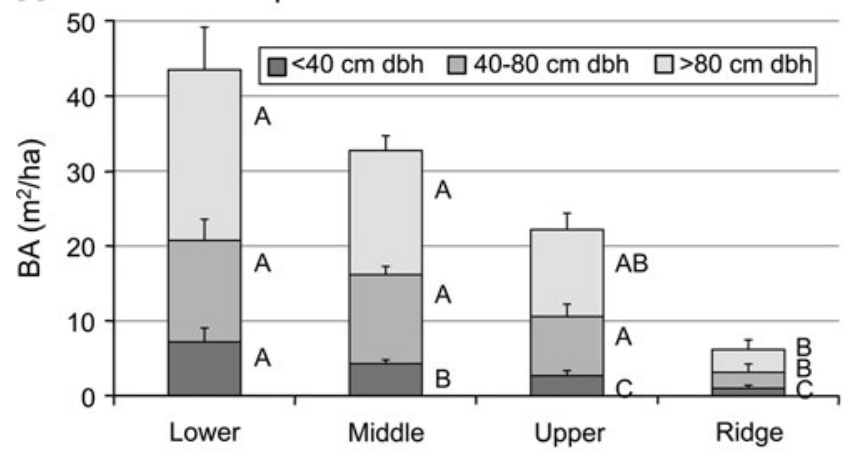

B Fire-tolerant Species

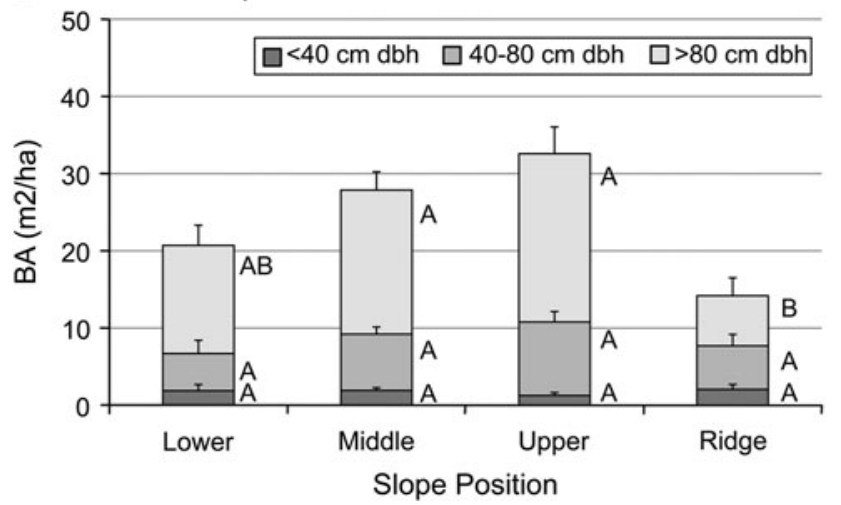

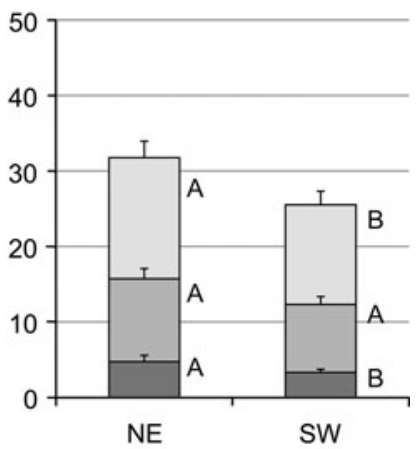

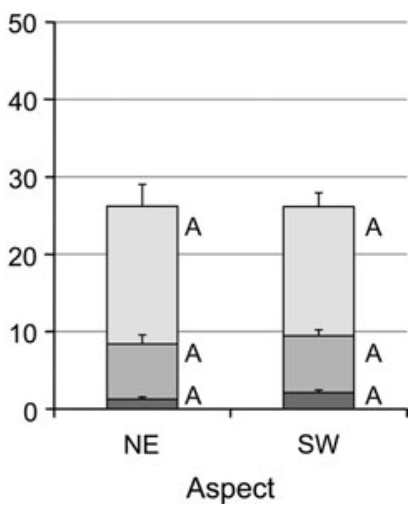

Figure 3. Average basal area of live trees by slope position (lower, middle, upper, and ridge) and aspect (northeast includes $291^{\circ}-110^{\circ}$, southwest includes $111^{\circ}$ $290^{\circ}$ ), in three size classes for A fire-intolerant species (Abies concolor, Abies magnifica, Calocedrus decurrens, and Pseudotsuga menziesii); and B fire-tolerant species (Pinus ponderosa, Pinus jeffreyi, Pinus lambertiana, Quercus kellogii,

\section{Live Tree and Understory Structure}

Axes in NMS analyses including all structure and just overstory variables had low eigenvalues and there was no clear pattern of association with recent fire record (results not shown). In contrast, the NMS analysis of understory variables suggests an association with sample site fire event characteristics. Topographic characteristics such as TRMI did not have a significant association with data patterns in the NMS analysis of understory. After 500 iterations, the NMS solution had three axes, with a final stress of 12.01 and final instability of 0.00008 . Axis 1 (0.419 of the variance) separated plots by species composition, shrub cover, and density of trees less than $40 \mathrm{~cm}$ dbh, with small tree density tending to increase in an opposing direction to shrub cover and percentage of fire-tolerant species (Figure 4). Char height was correlated with this axis $\left(r^{2}=0.105\right)$, with plots with greater char height having a lower density of small-trees, and and Quercus chrysolepis). Error bars show the upper half of the standard error for each size class within a topographic category. The number of plots included in calculating average and standard error for each topographic category are given in Table 2. Size classes with different letters are significantly different $(P<0.05)$ across slope position categories and between the two aspect classes.

greater shrub cover and percentage of fire-tolerant species. Axis 2 (0.272 of the variance) separated plots mainly by regenerating tree density. Years since fire was correlated with this axis $\left(r^{2}=0.115\right)$, with density of regenerating trees increasing with increasing time since last burn (Figure 4). Axis three (not shown) explained the least variability (0.198 of the variance), and separated plots mainly by differences in shrub cover.

Variation in shrub density was associated with fire record variables. The highest shrub cover, $41.7 \%$, associated with a branch in the CART analysis occurred on sites that had experienced more frequent-fires (that is, more than two fires in the last 65 years), with the last two fires being less than 9 years apart. Shrub cover was comparably high, $38.8 \%$, on sites that had burned less frequently (ten or more years between fires, eleven or more years since the last fire), but with at least one fire burning more intensely (char height $\geq 2.6 \mathrm{~m}$ ). 


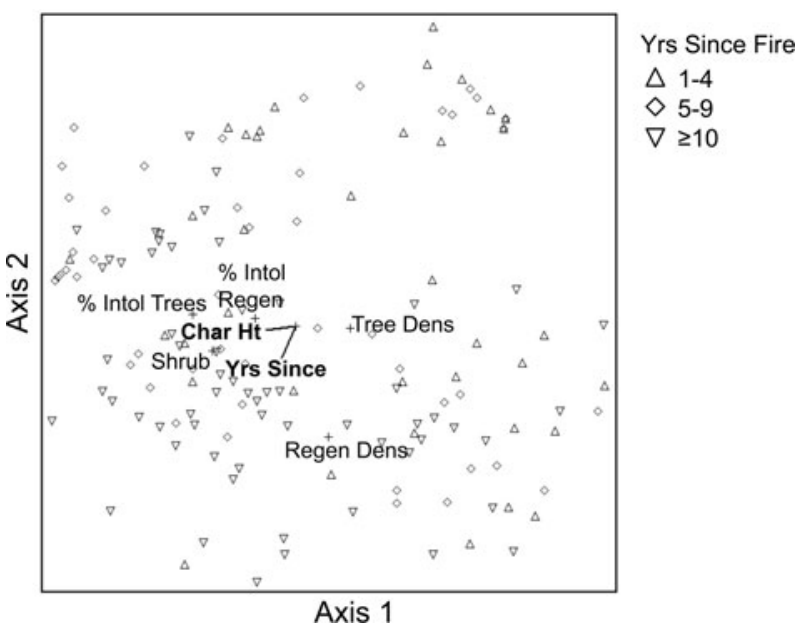

Figure 4. Bi-joint plot from ordination of forest understory structure and composition. Variables in the primary matrix are density of trees $5-40 \mathrm{~cm}$ dbh (Tree Dens), proportion of shade-intolerant species for trees $5-40 \mathrm{~cm}$ dbh (\% Intol Trees) and regenerating trees (\% Intol Regen), density of regenerating trees (Regen) and shrub cover (Shrub). Variables in the secondary matrix that had $r^{2}>0.1$ with an ordination axis were time since last fire (Yrs Since) and mean char height on tree and snag boles (Char $\mathrm{Ht}$ ).

Intermediate shrub cover, $18.6 \%$, was associated with sites that had experienced two fires within 9 years of each other, but no other fires within the last 65 years. The lowest shrub density, $7.8 \%$, occurred on sites that had ten or more years between fires, with the most recent fire occurring in the last 11 years (Figure $5 \mathrm{~A}$ ).

Fire intensity, and to a lesser extent topographic position, were associated with the density of stems less than $40 \mathrm{~cm} \mathrm{dbh}$. The lowest small tree densities were in plots with average char height of at least $3.3 \mathrm{~m}$, and the second lowest density corresponded to plots with intermediate char height of $2.1-3.3 \mathrm{~m}$. For those plots that had average char height less than $2.1 \mathrm{~m}$, topography became an influence with upper-slope and ridge-top plots having fewer smalltrees than lower and middle slope plots. For lower and middle slope plots, recent fire history was a further influence, with shorter time between fires leading to a greater density of small-trees (Figure $5 \mathrm{~B}$ ).

Variation in basal area of trees of at least $80 \mathrm{~cm}$ dbh was associated with differences in topographic measures. The first split in the regression tree corresponded to slope position, separating ridge-top plots from lower, middle and upper-slope plots. The second split corresponded to elevation, with plots below $1692 \mathrm{~m}$ having fewer large trees. Of the plots

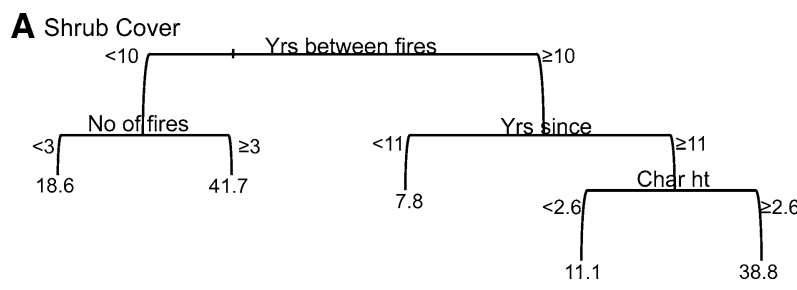

B Stem Density of $<40 \mathrm{~cm}$ dbh

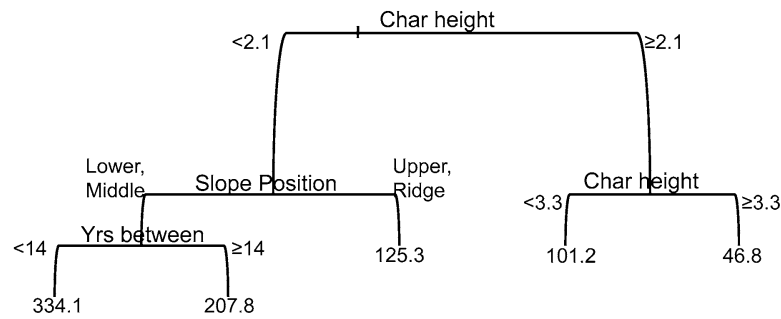

C Basal Area of trees $\geq 80 \mathrm{~cm} \mathrm{dbh}$

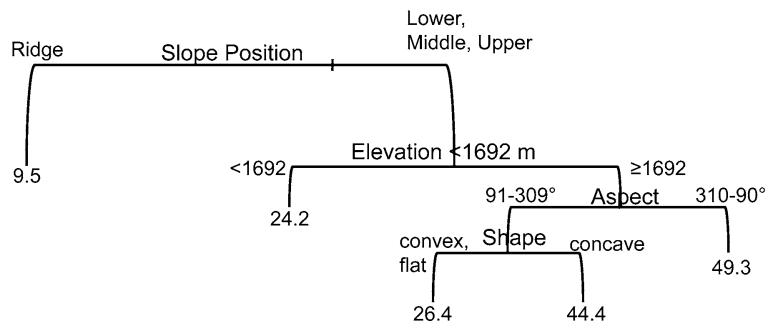

Figure 5. Classification and regression tree analysis for $\mathbf{A}$ shrub cover $(\%)$, B density $\left(\mathrm{ha}^{-1}\right)$ of live stems $\leq 40 \mathrm{~cm}$ $\mathrm{dbh}$, and $\mathbf{C}$ Basal area $\left(\mathrm{m}^{2} / \mathrm{ha}\right)$ of live stems $\geq 80 \mathrm{~cm} \mathrm{dbh}$. Char ht mean highest char height $(\mathrm{m})$ on all tree and snag boles within a plot, Yrs between number of years between the most recent and the second most recent fires, No of fires total number of fires in the last 65 years, Yrs since number of years since the most recent fire.

above $1692 \mathrm{~m}$, those between $310^{\circ}$ and $90^{\circ}$ had the greatest quantity of large trees. Among the other aspects, slope configuration had an effect, with concave plots having greater basal area than convex and flat plots (Figure 5C).

\section{Discussion}

Active-fire forest structure was highly heterogeneous and appears to result from the interaction of topographic differences in productivity and recent fire history effects on stand development. Differences in understory vegetation and small tree density were mainly associated with fire effects, with greater fire intensity promoting shrubs and seedlings, but limiting the survival of small-trees. Shorter fire intervals favored shrubs and small tree survival, whereas longer fire intervals favored seedlings and saplings. Large and intermediate trees 
were more strongly influenced by topography, with more mesic sites supporting greater tree densities, particularly of fire-intolerant species, and higher fuel loads. Ridges had the lowest productivity in terms of basal area and fuel loads, and were structurally distinct from other topographic positions. Management efforts to increase forest heterogeneity might use topography as a guide for varying stand structure and composition.

Our results should be treated with caution due to several study limitations. First, our approximation of an active-fire regime was imperfect and highly variable. Many study areas did not have fire reintroduced until the 1970s or later and thus were subject to a departure from the effects of frequentfire for a number of decades. Maximum fire intensity and the resulting stand structure appear to be influenced by a legacy of several decades of fuel loading. We believe the conditions we assessed may be more relevant for most forest managers, but they should not be considered an approximation of pre-European forest structure. Second, our data are specific to the Sierra Nevada, and values for stand structure variables are most indicative of mixedconifer forests. Relative differences in forest conditions between topographic categories, however, should be broadly applicable to many coniferous forests that historically had frequent, low-intensity fire regimes. Finally, our study could not directly separate the influence of fire frequency, inferred intensity, and site productivity on forest structure and fuels when it is likely these three factors are confounded. Topography can affect forest vegetation both directly, with contributing factors such as soil moisture (Scholl and Taylor 2010), soil thickness (Meyer and others 2007), and microclimate (Abella and Denton 2009), and indirectly by differences in fire intensity (Beaty and Taylor 2001) and frequency (Taylor and Skinner 2003). We make some inferences about which of these factors may influence particular stand structures based on correlations, but our study did not directly measure or assess causal mechanisms. In general, forest conditions were highly variable, reducing the number of significant differences between topographic categories. Trends in data suggest there may be additional topographic differences but a larger sample size and pre- and post-burn sampling would help better identify how topography may influence active-fire forest structure and composition.

Although there was high variability between individual plots, overall there were several significant differences in forest structures between different topographic positions. Similar to other studies we found an effect of topography on both tree density (Underwood and others 2010) and species composition (Taylor and Skinner 2003; Beaty and Taylor 2007; Scholl and Taylor 2010). Our study suggests an important factor influencing this difference is trees less than $40 \mathrm{~cm}$ dbh, which decrease in density and fire-intolerant composition with increasing maximum fire intensity. Smaller fire-intolerant trees generally have greater mortality from fire than do larger trees or more fire-tolerant species (Stephenson 1999). We were not able to determine which fire caused greater char height and therefore likely contributed to this effect on small tree densities, but previous work suggests that greater numbers of small fire-intolerant trees are removed in first entry burns as compared to successive fires (Webster and Halpern 2010). A longer interval between the two most recent fires was also associated with a lower density of small trees possibly due to greater fuel accumulations increasing components of fire intensity such as fire duration, which would not be evident from char height but could still contribute to mortality. Relatively high shrub cover was associated with two different fire patterns. Shrub cover increased with more frequent-fire, but it was also greater when the interval between fires was longer and maximum fire intensity, as inferred from char height, was high. Webster and Halpern (2010) found that shrubs were sparse in unburned forest, but increased in cover over time following fire. When already present at a site, shrubs typically undergo an initial decrease in cover, but increase their number of sprouts following fire (Kauffman and Martin 1990). Burn condition heterogeneity may promote different forest understory responses across a landscape, with areas burning at lower intensity promoting tree regeneration and higherintensity or more frequently burned areas creating shrub habitat.

Overstory forest structure was more highly correlated with topographic variation in site moisture regardless of particular fire frequency or maximum intensity. The greatest basal area of large trees and highest canopy cover occurred on northeast facing slopes and in concave microsites. Among ridge-top plots, there was no relationship between char height and total basal area (a measure dominated by large trees), but there was a negative relationship between char height and small tree density. This implies that basal area may be more directly affected by a site's productivity, whereas small tree density is more influenced by fire intensity. In general, ridges had a greater number of significantly different structural attributes compared to 
other slope positions, including lower canopy cover, stem density, basal area, quadratic mean diameter, and fuel loads. Ridges tend to have higher fire intensities (Beaty and Taylor 2001), lower moisture availability, and shallower soils (Urban and others 2000). The combination of low productivity and a more severe fire regime may be responsible for creating such distinct forest conditions on ridges, as compared to other topographic positions.

Tree size class distribution in this study suggests several decades of fire suppression may have persisting effects on forest composition and resilience even after reintroduction of two or more lowintensity burns. Although absolute density varied between plots and topographic positions, across all sites we found a consistent pattern of the greatest numbers of trees in the second smallest size class, many of which were shade-tolerant, fire-intolerant species. Tree establishment can be coincident with quiescent intervals in the fire record (Brown and $\mathrm{Wu}$ 2005), suggesting this size class may have established in the period between the onset of fire suppression and the reintroduction of fire. Collins and others (2011) found a better approximation of historical structure and composition when old forests burned at moderate rather than low-severity because higher-intensity was needed to kill many intermediate size trees following decades of fire suppression. Trees in this size class may escape mortality in lower-severity burns, but will eventually reach a size where they replace the large trees currently dominated by fire-tolerant pines. Studies suggest white fir, which dominates the fireintolerant stems, is more sensitive to drought stress than fire-tolerant pines (Ferrell and others 1994; Hurteau and others 2007), possibly making these future forests less resilient to droughts that may increase with changing climate conditions (Westerling and others 2006).

Our data support many of the current restoration guidelines for desired conditions of mixed-conifer forest with three noteworthy exceptions. We found much higher levels of shrub cover $(17 \%)$ than are generally present in most fire-suppressed forests (often $<5 \%$ ). Currently in the Sierra Nevada there are no guidelines for increasing shrub cover even though it is important habitat for many songbirds (Beedy 1981; Siegel and DeSante 2003) and small mammals (Sakai and Noon 1993; Coppeto and others 2006), and can diversify tree age and size distribution through its affects on regeneration dynamics (Gray and others 2005; Nagel and Taylor 2005). Second, we found fairly high levels of coarse woody debris (CWD) $(9.1$ snags/ha $\geq 50 \mathrm{~cm} \mathrm{dbh}$ and $10.3 \mathrm{logs} / \mathrm{ha}$ with a diameter $\geq 50 \mathrm{~cm}$ ) even though CWD is often considered ephemeral in active-fire forests (Morrison and Raphael 1993). These structures are important components of wildlife habitat (North and others 2009) and may be under represented in fuels-treated forests where current guidelines are vague (SNFPA 2004). Finally, we found variability in forest structure associated with both topographic position and fire metrics suggesting active-fire landscapes have a range of fuel conditions, tree densities, and canopy cover that would provide a diverse array of habitat for wildlife. Some current management practices in the Sierra Nevada set a standard target such as 40 $50 \%$ canopy cover (SNFPA 2004) that may not be appropriate for all forested areas such as those on ridge-tops. Forest treatments that incorporate more heterogeneity may be able to simultaneously reduce fuel loads, increase forest resilience to drought and wildfire, and provide habitat for sensitive species associated with high canopy closure and stem density.

A common strategy for managing forests under a changing climate is to promote forest resiliency (Millar and others 2007; Stephens and others 2010), often by thinning smaller trees and reducing surface fuels to reduce both the risk of catastrophic wildfire (Agee and Skinner 2005) and tree stress due to competition for scarce soil moisture (Sala and others 2005; Zou and others 2008). Scientists and managers, however, have had little information on what numbers of small and intermediate sized trees are sufficient for the future development of large trees, general guidelines for dead wood density and shrub cover, or how these factors may vary with topographic differences in productivity and fire regimes. Our study suggests that under an active-fire regime the interaction between site productivity and fire history creates highly heterogeneous conditions, providing greater habitat variability and fire-resiliency than is present in firesuppressed forests or than is often created by fuels reduction treatments.

\section{ACKNOWLEDGMENTS}

We would like to thank Cristin Walters for tireless field assistance; Tony Caprio (Sequoia/Kings Canyon N.P.), Jan van Wagtendonk (Yosemite N.P.), and Ross Gerrard (USFS) for help identifying sample sites; Neil Willits for statistical advice, and the USFS Pacific Southwest Research Station for financial support. We would also like to thank two anonymous reviewers, whose suggestions were very helpful in improving the clarity of the manuscript. 


\section{REFERENCES}

Abella SR, Denton CW. 2009. Spatial variation in reference conditions: historical tree density and pattern on a Pinus ponderosa landscape. Can J For Res 39:2391-403.

Agee JK, Skinner CN. 2005. Basic principles of forest fuel reduction treatments. For Ecol Manage 211:83-96.

Andrews P, Rothermel R. 1982. Charts for interpreting wildland fire behavior characteristics. General Technical Report INT131. U.S. Department of Agriculture, Forest Service, Intermountain Forest and Range Experiment Station, Ogden, UT.

Beaty RM, Taylor AH. 2001. Spatial and temporal variation of fire regimes in a mixed conifer forest landscape, Southern Cascades, California, USA. J Biogeogr 28:955-66.

Beaty RM, Taylor AH. 2007. Fire disturbance and forest structure in old-growth mixed conifer forests in the northern Sierra Nevada, California. J Veg Sci 18:879-90.

Beedy EC. 1981. Bird communities and forest structure in the Sierra Nevada of California. Condor 83:97-105.

Bekker MF, Taylor AH. 2001. Gradient analysis of fire regimes in Montane Forests of the Southern Cascade Range, Thousand Lakes Wilderness, California, USA. Plant Ecol 155:15-28.

Brown JK. 1974. Handbook for inventorying downed woody material. General Technical Report INT-16. U.S. Department of Agriculture, Forest Service. Ogden, Utah: Intermountain Forest and Range Experiment Station. p 24.

Brown PM, Wu R. 2005. Climate and disturbance forcing of episodic tree recruitment in a southwestern ponderosa pine landscape. Ecology 86:3030-8.

Canadell JG, Raupach MR. 2008. Managing forests for climate change mitigation. Science 320:1456-7.

Collins BM, Kelly M, van Wagtendonk JW, Stephens SL. 2007. Spatial patterns of large natural fires in Sierra Nevada wilderness areas. Landscape Ecol 22:545-57.

Collins BM, Everett RG, Stephens SL. 2011. Impacts of fire exclusion and recent managed fire on forest structure in old growth Sierra Nevada mixed-conifer forests. Ecosphere 2:art51.

Coppeto SA, Kelt DA, Van Vuren DH, Wilson JA, Bigelow S. 2006. Habitat associations of small mammals at two spatial scales in the northern Sierra Nevada. J Mammal 87:402-13.

ESRI. 2008. ArcGIS version 9.3. ESRI, Redlands, CA, USA.

FAO. 2005. Global forest resource assessment. Rome: Food and Agriculture Organization of the United Nations.

Ferrell GT, Otrosina WJ, Demars CJ Jr. 1994. Predicting susceptibility of white fir during a drought-associated outbreak of the fir engraver, Scolytusventralis, in California. Can J For Res 24:302-5.

Franklin JF, Fites-Kaufmann JA. 1996. Assessment of late-successional forests of the Sierra Nevada. Sierra Nevada ecosystem project, final report to Congress, Davis. pp 627-62.

Fulé PZ. 2008. Does it make sense to restore wildland fire in changing climate? Restor Ecol 16:526-31.

Gray AN, Zald HSJ, Kern RA, North M. 2005. Stand conditions associated with tree regeneration in Sierran mixed-conifer forests. Forest Sci 51:198-210.

Hessburg P, Salter R, James K. 2007. Re-examining fire severity relations in pre-management era mixed conifer forests: inferences from landscape patterns of forest structure. Landscape Ecol 22:5-24.

Hurteau M, Zald H, North M. 2007. Species-specific response to climate reconstruction in upper-elevation mixed-conifer for- ests of the western Sierra Nevada, California. Can J For Res 37:1681-91.

Insightful Corporation. 2007. S-PLUS. Seattle, WA, USA.

Kauffman JB, Martin RE. 1990. Sprouting shrub response to different seasons and fuel consumption levels of prescribed fire in Sierra Nevada mixed conifer ecosystems. Forest Sci 36:748-64.

Keane RE, Hessburg PF, Landres PB, Swanson FJ. 2009. The use of historical range and variability (HRV) in landscape management. For Ecol Manage 258:1025-37.

Keeley JE. 2009. Fire intensity, fire severity and burn severity: a brief review and suggested usage. Int. J. Wildland Fire 18:11626.

Laughlin DC, Bakker JD, Stoddard MT, Daniels ML, Springer JD, Gildar CN, Green AM, Covington WW. 2004. Toward reference conditions: wildfire effects on flora in an old-growth ponderosa pine forest. For Ecol Manage 199:137-52.

Levene H. 1960. Robust tests for equality of variances. In: Olkin I, Ed. Stanford studies in mathematics and statistics. Palo Alto (CA): Stanford University Press. p 278-92.

Maser C, Trappe JM. 1984. The seen and unseen world of the fallen tree. In: U.S. Department of Agriculture, Forest Service, Pacific Northwest Research Station, Portland, p 56.

McCune B, Grace JB. 2002. Analysis of ecological communities. Gleneden Beach (OR): MjM Software Design.

McCune B, Mefford MJ. 2006. PC-ORD. Multivariate analysis of ecological data. Gleneden Beach (OR): MjM Software.

Meyer MD, North MP, Gray AN, Zald HSJ. 2007. Influence of soil thickness on stand characteristics in a Sierra Nevada mixed-conifer forest. Plant Soil 294:113-23.

Millar CI, Woolfenden WB. 1999. The role of climate change in interpreting historical variability. Ecol Appl 9:1207-16.

Millar CI, Stephenson NL, Stephens SL. 2007. Climate change and forests of the future: managing in the face of uncertainty. Ecol Appl 17:2145-51.

Miller JD, Thode AE. 2007. Quantifying burn severity in a heterogeneous landscape with a relative version of the delta Normalized Burn Ratio (dNBR). Remote Sens Environ 109:66-80

Miller JD, Safford HD, Crimmins M, Thode AE. 2009. Quantitative evidence for increasing forest fire severity in the Sierra Nevada and Southern Cascade Mountains, California and Nevada, USA. Ecosystems 12:16-32.

Morrison ML, Raphael MG. 1993. Modeling the dynamics of snags. Ecol Appl 3:322-30.

Nagel TA, Taylor AH. 2005. Fire and persistence of montane chaparral in mixed conifer forest landscapes in the northern Sierra Nevada, Lake Tahoe Basin, California, USA. J Torrey Bot Soc 132:442-57.

Nesmith JCB, Caprio AC, Pfaff AH, McGinnis TW, Keeley JE. 2011. A comparison of effects from prescribed fires and wildfires managed for resource objectives in Sequoia and Kings Canyon National Parks. For Ecol Manage 261:1275-82.

North M, Innes J, Zald H. 2007. Comparison of thinning and prescribed fire restoration treatments to Sierran mixed-conifer historic conditions. Can J For Res 37:331-42.

North M, Stine P, Zielinski W, Stephens S. 2009. An ecosystem management strategy for Sierran mixed-conifer forests General Technical Report. PSW-GTR-220. U.S. Department of Agriculture, Forest Service, Pacific Southwest Research Station, Albany, CA. 
Parker AJ. 1982. The topographic relative moisture index: an approach to soil-moisture assessment in mountain terrain. Phys Geogr 3:160-8.

Sakai HF, Noon BR. 1993. Dusky-footed woodrat abundance in different-aged forests in Northwestern California. J Wildl Manag 57:373-82.

Sala A, Peters GD, McIntyre LR, Harrington MG. 2005. Physiological responses of ponderosa pine in western Montana to thinning, prescribed fire and burning season. Tree Physiol 25:339-48.

SAS Institute. 2008. Cary, NC, USA.

Scholl AE, Taylor AH. 2010. Fire regimes, forest change, and self-organization in an old-growth mixed-conifer forest, Yosemite National Park, USA. Ecol Appl 20:362-80.

Shapiro SS, Wilk MB. 1965. An analysis of variance test for normality (complete samples). Biometrika 52:591-611.

Siegel RB, DeSante DF. 2003. Bird communities in thinned versus unthinned Sierran Mixed Conifer Stands. Wilson Bull 115:155-65.

Skinner CN, Chang C. 1996. Fire regimes, past and present. Sierra Nevada ecosystem project, final report to Congress. Centers for Water and Wildland Resources, University of California, Davis, Davis. pp 1041-69.

SNFPA. 2004. Sierra Nevada forest plan amendment: final environmental impact statement. In: U.S. Department of Agriculture, Forest Service, Pacific Southwest Research Station, Vallejo, CA, USA.

Stephens SL, Fule PZ. 2005. Western pine forests with continuing frequent fire regimes: possible reference sites for management. J Forest 103:357-62.

Stephens SL, Skinner CN, Gill SJ. 2003. Dendrochronologybased fire history of Jeffrey pine-mixed conifer forests in the Sierra San Pedro Martir, Mexico. Can J For Res 33:1090-101.

Stephens SL, Fry DL, Franco-Vizcaino E. 2008. Wildfire and spatial patterns in forests in Northwestern Mexico: the United States wishes it had similar fire problems. Ecol Soc 13:12.

Stephens SL, Millar CI, Collins BM. 2010. Operational approaches to managing forests of the future in Mediterranean regions within a context of changing climates. Environ Res Lett 5:9.

Stephenson NL. 1999. Reference conditions for giant sequoia forest restoration: structure, process, and precision. Ecol Appl 9:1253-65.
Taylor AH. 2010. Fire disturbance and forest structure in an oldgrowth Pinus ponderosa forest, southern Cascades, USA. J Veg Sci 21:561-72.

Taylor AH, Skinner CN. 2003. Spatial patterns and controls on historical fire regimes and forest structure in the Klamath Mountains. Ecol Appl 13:704-19.

Underwood EC, Viers JH, Quinn JF, North M. 2010. Using topography to meet wildlife and fuels treatment objectives in fire-suppressed landscapes. Environ Manage 46:809-19.

Urban DL, Miller C, Halpin PN, Stephenson NL. 2000. Forest gradient response in Sierran landscapes: the physical template. Landscape Ecol 15:603-20.

van Mantgem PJ, Schwilk DW. 2009. Negligible influence of spatial autocorrelation in the assessment of fire effects in a mixed conifer forest. Fire Ecol 5:116-25.

van Mantgem PJ, Stephenson NL. 2007. Apparent climatically induced increase of tree mortality rates in a temperate forest. Ecol Lett 10:909-16.

van Mantgem PJ, Stephenson NL, Byrne JC, Daniels LD, Franklin JF, Fule PZ, Harmon ME, Larson AJ, Smith JM, Taylor AH, Veblen TT. 2009. Widespread increase of tree mortality rates in the Western United States. Science 323:521-4.

van Wagtendonk JW. 2007. The history and evolution of wildland fire use. Fire Ecol 3:3-17.

Virah-Sawmy M, Gillson L, Willis KJ. 2009. How does spatial heterogeneity influence resilience to climatic changes? Ecological dynamics in southeast Madagascar. Ecol Monogr 79:557-74

Webster KM, Halpern CB. 2010. Long-term vegetation responses to reintroduction and repeated use of fire in mixed-conifer forests of the Sierra Nevada. Ecosphere 1:art9.

Westerling AL, Hidalgo HG, Cayan DR, Swetnam TW. 2006. Warming and earlier spring increase western US forest wildfire activity. Science 313:940-3.

Zar JH. 2010. Biostatistical analysis. Upper Saddle River (NJ): Prentice Hall.

Zou CB, Breshears DD, Newman BD, Wilcox BP, Gard MO. 2008. Soil water dynamics under low-versus high-ponderosa pine tree density: ecohydrological functioning and restoration implications. Ecohydrology 1:309-15. 